\title{
Negative Interest Rate and Helicopter Money: The Feasibility of Extreme Economic Policies for UK under Covid-19
}

\author{
Yiming Cheng ${ }^{1, *}$
}

\author{
${ }^{1}$ Westa College, Southwest University, Chongqing 400715, China \\ *Corresponding author. Email: 18625887306@163.com
}

\begin{abstract}
Since the outbreak of Covid-19, the UK's GDP has continued its downward spiral. In addition, the UK government has urgently introduced a series of economic stimulus policies to counter the negative impact of the Great Lockdown on its economy. In the short run, as the policy was introduced, both UK GDP and inflation rate have risen compared to the previous period, but the positive impact of these policies is becoming weaker and there is a significant slowdown in its growth on the UK's economy. Therefore, this article aims to analyze two extreme policies, including negative interest rate and helicopter money, which may boost UK's economy. Through second-hand data, these extreme policies are likely to bring about a series of side effects, such as hyperinflation, which can be shown in dramatic devaluation of the German Mark in 20th century. However, based on this research, it can be known that in the face of the continuing impact of Covid-19, the economic situation in the UK now seems to suggest that it is time for these extreme economic policies to come into play. And for the UK, they must consider minimizing the risks associated with their policies at present.
\end{abstract}

Keywords: Covid-19, Monetary policy, Fiscal policy, Negative interest rate, Quantitative Easing, Helicopter money

\section{INTRODUCTION}

The outbreak of Covid-19 in 2020 has a huge impact on the world economy. In the face of the continued economic downturn, governments and central banks of various countries have responded and introduced a series of new policies to accelerate economic recovery. The United Kingdom, as one of the countries that have been most severely affected by the epidemic, has experienced a sharp decline in GDP. The British government has urgently introduced a series of fiscal policies including lower interest rates and Quantitative Easing to deal with the new round of economic shocks under this epidemic. However, after the implementation of the policy, the British economic indicators continued to weaken, and the domestic economic situation has not been significantly improved, so extreme policies such as "negative interest rates" and "helicopter money" are reintroduced. Through analysis of the current situation of the British economy and the limitations of economic policies, this article would explore the feasibility of "negative interest rates" and "helicopter money" on the British economic recovery.

\section{CURRENT SITUATION OF UK'S ECONOMY}

\subsection{Overview based on GDP and CPI of UK}

GDP, which is short for Gross Domestic Product, is recognized as the best indicator of the country's economic conditions. Measured by month, the monthly GDP in October 2020 is $7.9 \%$, which is $0.4 \%$ higher than that in September 2020 but lower than that in February 2020. Although the UK's GDP has grown for six consecutive months, its growth trend has slowed significantly since the largest increase in June 2020 with $9.1 \%$. From the short run, the growth in monthly GDP is directly related to the gradual relaxation of the British blockade policy. However, the four major service industries are still performing poorly, including travel agency tour operator and other reservation service and 
related activities, Air transport, Creative arts and entertainment activities, and Rail transport.

$\mathrm{CPI}$ is Consumer Price Index and $\mathrm{CPIH}$ is the price index including the cost of the owner's house. Both of them are indicators used to measure inflation. Since the outbreak of Covid-19, the UK's annual inflation rates of CPI and CPIH have shown an overall downward trend. In November 2020, the CPI annual inflation rate index is $0.3 \%$, which is a $0.4 \%$ drop from $0.7 \%$ in October; and the CPIH annual inflation rate index is 0.6 , which is a $0.3 \%$ decline from the previous month'. In the short term, fluctuations in CPI and CPIH are caused by the instability of domestic prices due to the epidemic. But in the long run, the recurrence of the domestic epidemic, which replaced Brexit, has become an important source of the uncertainty on economy in UK [1].

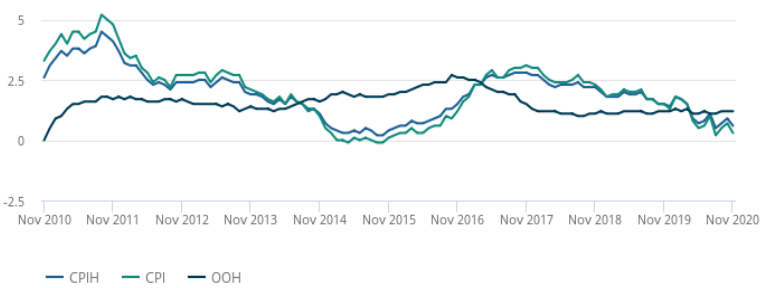

Figure 1 Office for National Statistic - Consumer price inflation

\subsection{UK's current economic stimulus policies}

The United Kingdom adopts monetary policy and fiscal policy to stimulate economic recovery. In monetary policy, as the British market is mature, the economic downturn is mainly due to the insufficient domestic demand. The government has implemented easy monetary policies to expand domestic demand and increase consumption.

Since the outbreak of Covid-19, Bank of England has cut interest rates twice. On March 11, 2020, Bank of England lowered its benchmark interest rate by 50 basis points to $0.25 \%$, and on March 19 it further cut interest rates to $0.1 \%$, which is basically close to zero interest rates.

At the same time, Bank of England implemented a Quantitative Easing (QE) injecting liquidity into the market through its existing British government bonds and sterling non-financial investment-grade corporate bonds. As of November 5, 2020, Bank of England has expanded its asset purchases to 845 billion pounds, far more than the central bank's purchase target of 745 billion pounds.

The British government also implements an expansionary fiscal policy, mainly by increasing investment to stimulate economic recovery.
On March 11, 2020, the UK Treasury proposed a $£ 30$ billion fiscal stimulus. In addition to $£ 7$ billion pounds aiding for businesses and individuals and $£ 5$ billion pounds supporting for public services in the fight against the epidemic, the policy also includes other economic stimulus measures in order to get the UK economy back on its feet quickly. Apart from this, the UK government also help companies by paying $80 \%$ wages of their employees if these companies allow their workers to take time off during the outbreak. And a $\$ 330$ billion loan guarantee is introduced for work resumption.

\section{LIMITATIONS OF UK'S CURRENT ECONOMIC STIMULUS POLICIES}

Compared with the worst situation in UK of the epidemic, although the British economy has shown signs of recovery, it is still experiencing a serious downturn compared with the same period in 2019. This shows that the role of a series of new stimulus policies in the United Kingdom are limited.

Since the outbreak of Covid-19, Bank of England has cut interest rates twice with maintaining its interest rates at $0.1 \%$. In normal circumstances, interest rates in a country are always positive, and of which in UK is now close to the bottom bound of zero interest rates. At the same time, some economists doubt the actual effect of lowering interest rates on the recovery of economy. Bill Evans, the chief economist of Westpac, showed that cutting in interest rate may damage the sentiment of customer [2]. Moreover, the declining interest rates have reduced the cost of borrowing for businesses, and some inefficient, near-bankrupt company can rely on borrowing from banks to keep operating, which can be a reasonable explanation to the stagnation of production. Thus, this would work against economic development [3].

Not only that, but the expansionary fiscal policy of the United Kingdom has also reached its limit. As of the end of July, the UK government debt exceeded £2 trillion for the first time, equivalent to $100.5 \%$ of UK GDP. The previous European debt crisis was due to the debt ratios of five European countries including Italy, Spain, Ireland, Portugal and Greece, which exceeded $100 \%$. When public debt is high and has the trend of rising, people's negative concerns about the government' $s$ future debt problems will prompt the emergence of the "Ricardian equivalence" as people realize that the current government tax cuts would have to be paid by themselves in the future [4]. So for the UK, there is very little room for fiscal policy to play its role in the future.

Similarly, as UK's economic stimulus, a considerable part of subsidies are based on the gradual liberalization of the blockade policy. For example, in 
order to combat the negative impact of the "Great Blockade" on the economy, the British government introduced "Eat out to help out scheme", that is, from Monday to Wednesday, if you go to a restaurant to eat, you only need to spend half the money. And after the day is over, the government will remain the rest to the restaurant, with the maximum limit of 10 pounds per person a day. However, at the time when the epidemic is still not fully under control in the UK, encouraging people to eat out could cause a new outbreak. And if the epidemic keeps recurring, it will cause a further heavy blow to the UK's already declining economy.

From this point of view, the current economic policies have little stimulus effects on the British economy, so some more extreme economic policies, such as "negative interest rates" and "helicopter money" have been brought up again. However, although extreme stimulus policies are rapidly stimulating recovery, it will also be accompanied by serious negative effects, such as hyperinflation. So for British government, there must be many obstacles to adapt these policies.

\section{ANALYSIS OF TWO POSSIBLE POLICIES FOR UK' S ECONOMIC IMPROVEMENT}

\subsection{Negative interest rate}

\subsubsection{The controversy of risk and function}

During the epidemic, the British government once expressed its attitude towards negative interest rates.

According to Gertjan Vlieghe, the Bank of England's monetary policy committee member, more monetary stimulus policies should be taken into consideration to stimulate the economy, including negative interest rates. And he expressed that without negative interest rates, the current interest rate plays a smaller part in recover the British economy. The risks brought by the negative interest rate must be accepted by the UK for further development. And it can be seen from the view of Gertjan Vlieghe that the British government has taken negative interest rates in its stimulus policy considerations.

However, negative interest rates, as an extreme monetary policy, have predictable negative effects. First of all, whether negative interest rates can effectively stimulate consumption is unknown. According to Keynes' liquidity trap, when the level of interest rates in a certain period is low to a certain limit, the interchangeability between short-term bonds or monetary policy instruments and money becomes so high that people expect interest rates to rise in the future and bond prices to fall, at which point the elasticity of demand for money becomes infinite and the space in which monetary policy can work is infinitely compressed. Therefore, with the conditions of the continued low interest rates of the British government, once the liquidity trap appears, the effect of lowering the interest rate will be small.

At the same time, negative interest rates may weaken the profitability of banks and other financial intermediaries and cause them to take excessive risks. Banks and other financial institutions are unwilling to lend due to the negative interest rate, which further increase asset prices and may cause distortions in the financial market. Not only that, but in countries which are known to have negative interest rates, except for the appreciation of the yen and the Swiss franc, other currencies depreciate on average after policy implementation [5]. The British pound has been previously affected by Brexit and fluctuates greatly. When combined with the impact of devaluation due to capital flows in international foreign exchange markets, it remains an open question whether the impact of rising domestic prices and the cost of living caused by the pound's poor performance in the foreign exchange markets can be offset by strong net exports.

\subsubsection{Existing experience and feasibility}

Based on existing experience, a number of countries that have implemented negative interest rates have effectively mitigated the adverse effects of negative interest rates through complementary policy measures. Since the financial crisis, developed economies have generally faced persistent economic weakness and below-target inflation, so central banks in many developed economies, including the Danish National Bank and the Bank of Japan, have pushed key policy rates (mainly deposit rates on excess commercial bank reserves) into negative territory over the past few years. To counteract the possible negative effects of negative interest rates, the European Central Bank maintains the stability of financial markets and reduces banks' risks by offering particularly favourable refinancing conditions for banks; the Bank of Japan, Sweden's Central Bank, the Dutch National Bank and the Swiss National Bank have also adopted additional measures to safeguard the returns of the financial system [3].

Meanwhile, in the face of the liquidity trap caused by negative interest rates, research has found that there are two policy options to get rid of this trap. The first one is to create effective demand for goods and services through external shocks, and the second one lowering the lower bound on nominal interest rates through a tax on money. However, only if the monetary authority can pay the interest on the currency, the second approach can work [6].

The current public debt in the UK has exceeded $100 \%$ of GDP and is on track to increase further. And there is a big question as to whether the Bank of 
England will have enough pounds to cover the currency payments required for the accompanying measures introduced to eliminate the negative impact of negative interest rates.

\subsection{Helicopter money}

\subsubsection{The definition of helicopter money}

In addition to negative interest rates, another extreme form of stimulus is the "Monetization of Financial Deficit", which is commonly known as "helicopter money". This extreme economic stimulus, which was initially very controversial when it was proposed by Nobel Prize-winning economist Milton Friedman, is undergoing a Paradigm shift, that is, it is being increasingly reconsidered and embraced in the current precipitous decline of the global economy.

Monetization of Financial Deficit is a method of combining monetary policy and fiscal policy. The central bank increases the supply of base money to provide financing for government deficits, thereby stimulating nominal aggregate demand. Compared with the UK's current Quantitative Easing policy, helicopter money is a more direct and faster economic stimulus method. And with the same amount of monetary, the Quantitative Easing policy takes a longer time, which implies the degree of $\mathrm{QE}$ stimulating government spending is usually weaker than the helicopter money [7]. And the marginal benefits of Quantitative Easing are becoming smaller and smaller, so the UK continues to increase the scale of asset purchases. Since the outbreak of the epidemic, the scale of asset purchases in the UK has far exceeded the $£ 745$ billion target set by Bank of England. Therefore, if the economy does not improve as expected, the helicopter money policy can be implemented with a controlled manner in the short term.

\subsubsection{Side effect and feasibility of helicopter money}

However, the most direct side effect of helicopter money is hyperinflation. Between 1922-1923, Germany's inflation rate was as high as $29,000 \%$. In addition to Germany, many countries in the 20th century experienced the similar hyperinflation. These were all caused by the unrestricted "helicopter money" policy [8] Therefore, although the current domestic inflation rate in the UK has not reached half of the $2 \%$ target set by the government in April, they still have to be alert to the drastic changes in the pound price which may be brought about by extreme policies in the future.

Simultaneously, more and more people are beginning to doubt how much of an economic stimulus helicopter money can bring. According to the findings of a new report by ING, nearly 12,000 people in 12 countries/regions across Europe (including the UK) were asked how they would spend $€ 2,400$ (without having to pay it back); and the study showed that only $26 \%$ of respondents said they would spend most of the money [6]. This is also in line with the Lucas critique that the effectiveness of policy is based on deceiving the public. Once the public knows what the government is really up to, the effectiveness of the policy is greatly diminished. Therefore, if the UK were to consider implementing helicopter money spreading to stimulate economic recovery, how and how much would be the tricky questions for the UK government and the central bank to face. In addition to hyperinflation and Lucas' critique, the actual difficulty and legitimacy of helicopter money are also the key bound to preventing the policy from entering the implementation [5].

In general, Monetization of Financial Deficit is indeed a powerful economic stimulus tool in theory, but its implementation in real worlds is difficult. So policy makers should only resort to these measures in emergency situations, otherwise it could trigger a more serious crisis. However, in the face of the dramatic impact of Covid-19 on the economy, it is time for the British government to consider the "helicopter money" policy [9].

\section{CONCLUSION}

The UK economy has been hit hard by Covid-19. In order to stimulate economic recovery, the UK government has introduced new monetary policies and fiscal policies to counter the negative impact of the Great Lockdown on its economy. Based on the analysis of the current state of the UK economy, while there is an upward trend, the pace of recovery has slowed significantly, which means the effect of the new economic stimulus is far from being able to bring the UK economy back to its pre-epidemic levels. And judging from the UK's current low level of interest rates and continually growing public debt, there is very little room left for conventional monetary and fiscal policy to work. Therefore, if the UK government wants to recover its economy further, it has to start considering the possibility of implementing extreme economic stimulus policies, such as negative interest rates and helicopter money. Although negative interest rates and helicopter money can have a direct and rapid effect on the economy, the risks they entail, including hyperinflation, are the reason why these two policies are so controversial. But as one of the countries affected seriously by Covid-19, the negative effects of negative interest rates and helicopter money are something it must accept in order to stimulate the British economic recovery. UK should avoid the possible risks of these two extreme policies as much as possible. Fortunately, there is a Paradigm shift in these both. A growing number of countries have implemented negative interest 
rates and helicopter money, so this implies that there is much experience for the UK to learn from.

\section{AUTHORS' CONTRIBUTIONS}

The author finished this paper through analysis and wrote this paper individually.

\section{ACKNOWLEDGMENTS}

First of all, I sincerely thank my teacher for helping me in completing the thesis. When I had doubts about my choice of topic, it was your inspiration which gave me new ideas and help me finally complete this paper. And I would like to express my gratitude to my family and my friends who have been supporting me in silence. Due to their material and spiritual support, I can successfully do this research of the subject. Finally, I want to express my gratitude again to all those who once have given me encouragement. Thanks for all your tolerance and understanding!

\section{REFERENCES}

[1] D. Altig, S. Baker, J. M. Barrero, N. Bloom, P. Bunn, $\mathrm{S}$. Chen, et al., Economic uncertainty before and during the Covid-19 pandemic, in Journal of Public Economics, 2020, Volume 191, DOI: https://doi.org/10.1016/j.jpubeco.2020.104274

[2] S. Kirchner, The Effect of Changes in Monetary Policy on Consumer and Business Confidence, in: Australian Economic Review, Wiley Online Library, 2020, pp.118-125, DOI: https://doi.org/10.1111/1467-8462.12365

[3] P. Arestis, Productivity and inequality in the UK: a political economy perspective, Review of Evolutionary Political Economy, 2020, pp.183-197, DOI: https://doi.org/10.1007/s43253-020-00006-3

[4] L. Reichlin, A. Turner, M. Woodford, Helicopter money as a policy option, in VoxEU. org, 2013.

[5] C. Arteta, M. A. Kose, M. Stocker, T. Taskin, Negative interest rate policies: Sources and implications, 2016, DOI: https://doi.org/10.1596/1813-9450-7791

[6] W. H. Buiter, N. Panigirtzoglou, Overcoming the zero bound on nominal interest rates with negative interest on currency: Gesell's solution, in The economic journal, 2003, pp.723-746, DOI: https://doi.org/10.1111/1468-0297.t01-1-00162

[7] Covid-19, Helicopter Money \& the Fiscal-Monetary Nexus, A Cukierman, Covid-19, Helicopter Money $\&$ the Fiscal-Monetary Nexus, in: CEPR Discussion Paper No. DP14734, 2020, pp.1-50.
[8] Bright, S. Janssen. Helicopter money: Loved, Not Spent, VoxEU. Online available, http://voxeu.org/article/helicopter-money-loved-not spent, accessed on 13 January 2017.

[9] R. Baldwin, B. W. di Mauro, Mitigating the COVID Economic Crisis: Act Fast and Do Whatever, 2020. 